\title{
Overcoming the Crisis: The Changing Profile and Trajectories of Latvian migrants
}

\author{
David McCollum, Elina Apsite -Berina, Maris Berzins, Zaiga Krisjane
}

\begin{abstract}
Taking mobility between Latvia and Western Europe as an empirical lens, this analysis explores the complex relationship between spatial disparities in earning potential and migration. The very dramatic shifts in the economic and political context against which migration from Latvia has occurred over the period 2004-2012 make it an especially apposite focus of research investigating the link between mobility and labour market circumstances. As an analytical starting point, conventional economic theory broadly explains the movement of workers from lower to higher wage regions. However this investigation seeks to contribute to understandings of the economic drivers of migration through consideration of the effects of the Great Recession on not only the volume of flows from Latvia to higher wage economies elsewhere in Europe, but also on the characteristics of the migrants themselves and of the processes that produce their mobility. This is undertaken through analysis of a large scale online survey of Latvian emigrants in five European countries. The findings point towards the Great Recession creating a distinctive cohort of reluctant 'crisis migrants'. Analytically the quantitative and qualitative attributes of this new phase of mobility raise a number of conceptually significant questions about understandings of the economy - migration nexus.
\end{abstract}

Key words: emigration, economic crisis, Latvia, online survey, labour migration.

\section{Introduction: contemporary labour migration in Europe}

The mobility trends that have arisen since the accession of the so-called A8 countries (Czech Republic, Estonia, Hungary, Latvia, Lithuania, Poland, Slovakia, Slovenia) to the European Union (EU) in 2004 have been the focus of considerable academic and policy interest. In the context of the principle of free movement within the EU and significant spatial disparities in earning potentials between Eastern and Western Europe, migration between the A8 states and higher wage regions has been substantial and chiefly driven by economic factors (Burrell, 2009). Broadly speaking, this body of research has viewed these substantial movements from a receiving rather than sending country perspective (Blanchflower et al, 2007; Dustmann et al, 2010; Stenning and Dawley, 2009). On the occasions when analysis has been extended to sending countries, it has perhaps understandably tended to focus on Poland as the most populous and significant of the A8 countries in terms of emigration. By contrast the other 
smaller A8 states have been relatively neglected by researchers studying contemporary intraEuropean migration flows (McCollum et al, 2013).

In terms of the evolution of migration from Eastern to Western Europe over the past decade, the existing literature points towards the existence of two key phases. Firstly the removal of legislative barriers to migration with the accession of the A8 countries to the EU in 2004 led to a significant flow of migrants westward (Burrell, 2009). These flows were mostly to the then booming economies of the UK and Ireland who, along with Sweden, were the only countries not to impose restrictions on the access of A8 workers to their labour markets in the form of 'transitional controls'. The predominately labour migrants constituting these movements have been termed 'accession migrants'. The second phase in contemporary Eastern to Western migration flows emerged with the onset of the Great Recession in 2008. This unprecedented economic downturn inevitably had a severe impact on labour market conditions in the counties that had received significant numbers of A8 migrants since 2004, leading to a slackening in demand for labour (migrant and non-migrant alike). However the Great Recession has had an even more dramatic impact on the economies of some A8 states (McCollum et al, 2013), leading to a second wave of East to West migration flows. These migrants have been termed 'crisis migrants'.

This analysis examines the quantitative and qualitative features of the initial accession and then crisis waves of East to West European migration. Conceptually this analytical framework hopes to aid understanding of one of the most longstanding and fundamental questions in migration studies: the relationship between migration and economic circumstances. Migratory processes occurring in the immediacy of the 2004 A8 Accession and mainly relating to significant spatial disparities in earning potential (accession migrants) will have been complicated by severe shifts in the business cycle in the period following the 2008 Great Recession (crisis migrants). These issues are explored in the context of migration from Latvia to higher wage regions in Europe. Latvia is an especially valuable lens through which the shifting dynamics of labour migration can be viewed given the very significant changes in the economic and institutional backdrop against which mobility has occurred in the decade since 2004. This analysis focuses on the following three specific research questions; 
1. To what extent are accession and crisis migrants distinctive in terms of their sociodemographic characteristics?

2. How effective are conventional neo-classical understandings of mobility in explaining recent patterns and processes of migration from Latvia?

3. What role does human capital play in the dynamics of accession and recession migration?

\section{Migration in changing economic and institutional contexts}

As with the many East-Central European countries that have been subject to significant political and economic transformations, Latvia has experienced some quite substantial population shifts in its recent history. These periods of mobility can be thought of as occurring in three main waves (Bleire et al, 2005; Hazans, 2011). Prior to the onset of World War I Latvia, as a part of the then Russian Empire, experienced substantial emigration, with around 15 per cent of the population leaving the country between the mid-nineteenth century and 1914. Latvia gained its independence in 1918, leading to some return migration. A second wave of emigration occurred during the turmoil of World War II and Latvia's subsequent incorporation into the Soviet Union (Tammaru et al, 2010). Latvia then experienced long periods of net in-migration from other parts of the Soviet Union, principally as a consequence of the Soviet policy of dispersing Russians to other parts of the Union (Eglite, 2009). It is the third and most recent wave of emigration from Latvia that is the focus of this analysis.

With the A8 accession to the EU in May 2004, large numbers of East-Central European citizens took advantage of the principle of the free movement of labour and participated in the economies of higher wage European countries. The experience of Latvia was similar to the other A8 states in that it too experienced significant emigration around this period; however in other ways it was quite distinctive. Latvia's economy performed relatively well following accession (rapid economic growth, low unemployment rates and one of the fastest increases in wage rates amongst the EU Member States (Kancs, 2010)), meaning that emigration pressure was not as pronounced as it was in many of the other A8 states at this time. Rapid economic growth and the outward migration of some workers meant that Latvia experienced domestic labour shortages and replacement labour migration flows into the country (Woolfson, 2009). However the Latvian economy entered severe recession at the beginning of 2008 (see Koyama, 2010 for an account of the factors that led to economic crisis in Latvia) and the 
subsequent 26 per cent decline in GDP over the following two years was the sharpest of any nation ever recorded (Weisbrot and Ray, 2010). Unemployment increased from 5 per cent at the end of 2007 to 23 per cent in 2010, the highest in Europe (Eurostat, 2010). Latvia experienced the greatest declines in employment rates, imports and retail sales between the second quarter of 2008 and the second quarter of 2009 in Europe (Eurostat, 2010). On some measures Latvia's economy has recovered remarkably quickly. For example in GDP growth has returned to positive levels, however unemployment levels have remained stubbornly high and remain above the EU average (Mačys, 2012).

Figures suggest that many Latvians migrated from Latvia to other parts of Europe in the years immediately following their Accession to the EU but that by 2006-2007 rates of emigration had slowed dramatically in conjunction with the tightening of the domestic labour market over this period (Kancs, 2010). However the rapid and severe collapse of the Latvian economy led to increased labour migration flows to elsewhere in Europe. Indeed Latvia now has one of the highest rates of demographic decline (losses of population through net migration and natural change) in Europe (Eurostat, 2010). As is evident in Table 1 the numbers of Latvians residing elsewhere in Europe has increased significantly in the period since the country's accession to the EU in 2004, with the UK by far the favoured destination of migrants. This analysis seeks to shed light on how the drivers of these flows and the characteristics of the migrants that constitute them have evolved since the monumental changes in the political and economic contexts against which mobility has occurred in the ten years since Latvia's EU accession in 2004.

Table 1: Latvian citizens residing in elsewhere Europe, 2004 and 2013

\begin{tabular}{|l|c|c|c|}
\hline Country & $\mathbf{2 0 0 4}$ & $\mathbf{2 0 1 3}$ & Change 2004 to 2013 \\
\hline United Kingdom & 4,429 & 71,834 & 67,405 \\
\hline Ireland & 6,266 & 20,341 & 14,075 \\
\hline Germany & 9,341 & 23,467 & 14,126 \\
\hline Norway & 534 & 8,490 & 7,956 \\
\hline Sweden & 934 & 4,506 & 3,572 \\
\hline Denmark & 905 & 4,204 & 3,299 \\
\hline Spain & 994 & 4,105 & 3,111 \\
\hline Italy & 690 & 2,322 & 1,632 \\
\hline Netherlands & 283 & 3,073 & 2,790 \\
\hline
\end{tabular}

Source: Authors analysis of figures from EUROSTAT 


\section{Economic drivers of migration: post-accession and crisis migrants}

The issues discussed above point to towards two distinct drivers of migration from Latvia over the past decade. The initial removal of legislative barriers to mobility in 2004 led to some movement westwards towards higher wage regions in Europe. A later and larger spike in emigration followed around 2008, induced by the economic turmoil associated with the Great Recession (King et al 2014; Blanchard et al, 2013). Whilst the existing migration literature has examined the patterns and processes of so-called accession migration from Eastern to Western Europe (Gillingham, 2010; McCollum et al, 2013), much less attention has been paid to the so-called crisis migration that has occurred since the Great Recession. This investigation seeks to contribute to these understandings by comparing the drivers and characteristics of accession and crisis migration and migrants from Latvia to elsewhere in Europe.

The migration literature can provide some theoretical explanation of how the accession and crisis migration flows might be expected to differ. A simple neo-classical framework could potentially account for the emigration that took place immediately following the accession (Chiswick, 2008). According to this perspective the removal of barriers to mobility (extension of the freedom of labour) will lead to mobility from lower to higher wage regions, in this case from Latvia to the UK and Ireland. Again in line with neo-classical expectations, improving economic conditions in Latvia prior to the onset of the Great Recession coincided with deceasing levels of emigration. From the migration literature, these initial migrants could be expected to have favourable levels of human capital relative to later migrants: so called 'pioneer migrants' move before, and are implicit in producing, the existence of migration channels between particular places, which make the process of mobility easier for subsequent migrants (Bakewell et al, 2011). The migrants who move independently of migration channels tend to be skilled and willing to take risks, given the relatively high cost and risks of early migration (de Haas, 2010). Recent timely research has demonstrated the feedback mechanisms whereby the presence of one group of migrants can influence the decisions and actions of those who come later (Bakewell et al, 2016). For example social media has been identified as a new form of feedback that increasingly shapes mobility decisions within migration corridors (Dekker et al, 2016). 
Whilst the relationship between accession migrants and economic factors could be understood in relatively broad terms using neo-classical explanations, the drivers of crisis migration and the characteristics of these migrants is perhaps less amenable to clear interpretation. The relationship between international labour migration and business cycles remains an unresolved issue in migration studies. In general weakening economic conditions lead to a fall in demand for immigrant labour (Fielding, 1997), with migrants bearing a disproportionate risk of losing their jobs during a downturn (Ahearne et al, 2009). This can be partly explained by migrants being overrepresented in sectors of the economy that are especially sensitive to recessions, such as construction for example (Somerville and Sumption, 2009). However these expectations have not been matched by actual patterns of migration since the Great Recession. Although the immigration of A8 nationals to the UK has declined since the onset of the recession, immigration remained significant over this period, with well over 400,000 labour migrants arriving over the period January 2008 to April 2011 (McCollum, 2012). These inflows could be explained by A8 immigrants serving particular 'functions' in the labour markets of Western European economies. As segmented labour market theory suggests, particular labour market structures can create a perennial need for 'flexible' immigrant labour (McCollum and Findlay, 2015). Research by Findlay et al (2010) and Fix et al (2009) has demonstrated that demand for A8 labour has confounded conventional understandings of the business cycle - migration nexus because of the specific functions that some migrant workers serve in Western European labour markets. Another criticism of the conventional business cycle - migration understanding is that it does not account for conditions in sending countries: reduced earnings and labour market opportunities in a country experiencing a downturn may well still be favourable to even less attractive economic conditions at home. Furthermore, some researchers have challenged purely economic explanations of crisis migration, emphasising how responses to the recession have varied according to the socio-economic status of migrants (King et al, 2014; Bygnes, 2015). Based on these understandings, the drivers of migration and characteristics of migrants from Latvia may differ in important ways between the period of accession migration and the later phase of crisis migration. This analysis hopes to contribute to understandings of the processes that lie behind these flows, especially the poorly understood link between businesses cycles and migration. 
Another contribution that the investigation aims to make is in the nascent field of research that explores the selectivity of post-accession migration from the A8 states. It has long been recognised that migration is a selective process, with economic migrants often being 'selfselected' for labour-market success relative to similar individuals who remain in their place of origin (Chiswick, 2008). What is less apparent from the literature is how the dynamics of migrant selectivity play out in the context of a 'perfect migration storm' (Okólski and Salt, 2014,2 ) of significant spatial differentials in wage levels, the sudden abrupt removal of legislative barriers to mobility and dramatic shifts in the business cycle in both migrant sending and receiving regions. Some research has explored the selectivity of recent out migration from Poland (Okólski and Salt, 2014; Kaczmarczyk and Okólski, 2008). Drawing on a Migrants Selectivity Index, these studies have identified two structurally different streams of recent migration from Poland. On one hand, migrants to the newly accessible British and Irish labour markets displayed many of the characteristics of 'pioneer migrants' (as such being young, well-educated and having good language skills), whereas recent Polish migrants to more traditional destinations such as Germany held lower levels of human capital. Whilst a little is now known about selectivity patterns from East and Central European states pre and post accession, less is understood about how the transition from accession to recession has shaped the selectivity mechanisms of potential migrants in these countries. In the Latvian context, most of this research has been conducted by the economist Mihails Hazans. This analysis (Hazans, 2011) argues that recent emigration from Latvia has taken place in two distinct waves, with crisis migrants being larger in number, geographically dispersed and well educated (including better language skills) relative to accession migrants. In this sense, recent migration from Latvia is of particular conceptual interest as it appears to confound the assumption in the literature (Lindstrom and Ramirez, 2010) that the human capital of migrant's declines as migration streams evolve. Indeed analysis of the aggregate characteristics of recent migrant workers in the UK points to a significant drop off in volume of highly educated A8 migrants over the period 2007-2013 (Migration Observatory, 2014). Similarly, Okólski and Salt (2014) find that the skill level of Polish migrants to Britain has declined over time. This analysis investigates temporal shifts in the human capital dynamics of migration trends using an innovative methodological approach involving Computer Assisted Web Interviewing (CAWI). This is described in the following section. 


\section{Research design}

An online internet based method was used to engage with Latvian migrants living in five key European destination countries: the UK, Ireland, Germany, Sweden and Norway. The motivation for this particular research approach was the recognition that existing statistical data on migration is ill-suited for understanding the drivers or characteristics of migration. As such a specialised online survey tool was deployed in an attempt to capture some of the mechanisms behind temporal shifts in the selectivity of migration. The use of Computer Assisted Web Interviews (CAWI) is an increasingly common research approach and has the benefit of being a versatile and relatively inexpensive means of collecting a large quantity of primary data, especially over geographically dispersed areas (Reips and Buffardi, 2012; Oiarzabal, 2012; McCollum and Apsite-Berina, 2015). In addition to being cost-efficient, online data collection methods can lessen problems with social desirability bias in surveys (see Hansen and Pedersen, 2012 for a discussion of the relative merits of CAWI compared to more traditional modes of data collection).

Growing access to information and communication technologies (ICTs) and the current state of human mobility is closely interrelated (Hamel, 2009; Kellerman, 2010). Technological developments facilitate the formation and flow of people, allow people to overcome timespace barriers and maintain community and family ties across different socio-spatial contexts. The extensive use of ICTs amplifies the opportunities for more transnational forms of migration and constitutes a fairly new dimension in the study of migration (Dekker et al, 2015; Oiarzabal, 2012). At the same time this is still very much an under-researched area, particularly regarding the study of the use of Social Network Sites (SNSs). SNSs are defined as websites that allow participants to construct a public or semi-public profile within the system which allows users to provide content to the World Wide Web and make possible the exchange of information (Boyd and Ellison, 2007; Reips and Buffardi, 2012). A common feature to SNSs is the assumption that people want to share information (Oiarzabal, 2012). Thus, via the SNSs it has become less difficult to access research populations from specific groups (such as migrants).

The survey was conducted in 2012 and administered through the Latvian SNS www.frype.com (www.draugiem.lv in Latvian), which is similar to the more widely known Facebook. This research method and SNS was selected as it is a social networking service that 
is hugely popular among Latvians and gathering data in this way has proved to be highly valuable based on similar research studies (see McCollum and Apsite-Berina, 2015; the ongoing ESF funded Emigrant Communities of Latvia project). Internet use is relatively prevalent in Latvia, with around three quarters of the population using the internet at least once a week (Internet Association of Latvia, Eurostat, 2014). More than half (58\%) of internet users are users of the www.frype.com SNS (ibid). With the consent of frype.com, the questionnaire was individually posted to the registered site users based on the geographical location of their IP (Internet Protocol) addresses and contained forty questions gathering data on respondents' demographic characteristics, geographical distribution, migration-related particularities and reasons for emigration. In addition, the questionnaire contained questions on the social and economic status of the migrant, her/his marital status, attachment to family, education and occupation. As is typical of samples based on questionnaire surveys, there are several limitations in this type of data, such as the representativeness of the sample relative to the general population. On the other hand, primary data resulting from the survey have an advantage over aggregate statistical data since the questionnaire provides information on motivations for emigration and also detects specific issues not usually covered by official statistics.

The final research population consisted of 2,565 people, of whom 1,117 lived in the UK, 618 lived in Ireland and 426 in Germany, while in Sweden and Norway together there were 404 respondents. The acquired dataset corresponds to the countries where the largest numbers of Latvian emigrants were concentrated. The respondents were aged between 16 and 73, although the greatest share of emigrants was observed in the 16-30 year old age cohort. Where possible the sample was representative; for example, in the case of the UK the sample corresponds with the general age composition of A8/Latvian migrants in the UK at that time (McCollum and Apsite-Berina, 2015). Overall 1,036 males and 1,529 females participated in the questionnaire survey. The greater volume of female respondents may be explained by two interrelated factors. Not only are women often more active users of online social media websites (Hargittai, 2008) but they also have a greater propensity to participate in scientific research (Galea and Tracy, 2007). In terms of skill level the survey was broadly representative of Latvian migrants to Europe, although those with tertiary education are slightly underrepresented (Hazans, 2012). 


\section{Results: uncovering the crisis migrant}

Table 2 displays the profile of recent migrants from Latvia living elsewhere in Europe, as derived from the online survey. The analysis disaggregates the sample according to whether the respondents were pre-crisis (those who emigrated from Latvia between 2004 and 2007) and crisis migrants (those who left between 2008 and 2012). From the figures below, it is possible to draw some conclusions about the typical characteristics of recent emigrants from Latvia, and to make wider inferences about how the Great Recession has impacted on the selectivity of migratory processes from relatively low to high wage economies.

One interesting aspect of the figures in Table 2 is that it seems that women appear to display greater propensity to migrate than men. This perhaps reflects the increasingly large part of labour migration flows that are constituted by women; the so-called feminisation of migration (Castles and Miller, 2009). Another noteworthy observation from Table 2 is the evidence of migrants being underemployed in their host economies. Around 85 per cent of the sample held at least secondary level education, yet around a third were in low-skilled jobs. Segmented labour market theory (Waldinger and Lichter, 2003), human capital explanations (Shields and Wheatley Price, 2001), the role of migrant social networks (Portes and Sensenbrenner, 1993) and migrants' 'dual frame of reference' (Piore, 1979) are amongst the explanations offered in the literature for these trends and these debates are not revisited here. Of the five countries included in the research, most migrants moved to the UK and Ireland, which is to be expected given the fact that these countries opened their labour markets to A8 nationals at an earlier stage than other European countries. The relative 'flexibility' of the labour markets in the UK and Ireland, migrant social networks and the fact that they are English speaking countries, may also explain the large volume of flows to them (Kahanec et al, 2009). A final remarkable aspect of the survey sample was that so many (77\%) had no intention of returning to Latvia. This sets in contrast to some other interpretations of A8 migration, which may have overemphasised the role of the free mobility of labour and inexpensive travel options producing apparent 'circular' intra-EU mobility (Dustmann and Weiss, 2007; Salt, 2008).

\section{The Great Recession and the emergence of the 'crisis' migrant}

Following on from the discussion of the general characteristics of recent emigrants above, the survey design allowed for comparisons to be made between those who left Latvia in the 
period immediately following the accession and those who did not leave until the recession. This approach contributes to efforts aimed at understanding how the mechanisms of migrant selectivity have been affected by the significant economic turmoil unleashed by the Great Recession. Key shifts in the profile of migrants since the onset of the recession include a growth in: younger migrants (aged 16-25), migrants who were previously unemployed in Latvia, low skilled employment in host economies and emigration from the capital city Riga and its suburban hinterland. In line with their relative economic performance since the recession, the attractiveness of the UK labour market to Latvians has grown compared to Ireland. Finally, recessionary phase migrants appear to be first time migrants and display a greater desire to return to Latvia relative to migrants who left during the accession phase (see Zaiceva and Zimmerman, 2012 and King et al 2014 for more information on how the recession has influenced the mobility intentions and patterns of East-Central European emigrants).

Table 2: Profile of recent Latvian emigrants (figures in percentages)

\begin{tabular}{|c|c|c|c|c|}
\hline & Variable & $\begin{array}{l}\text { Pre crisis migrants } \\
(2004-2007)\end{array}$ & $\begin{array}{l}\text { Crisis migrants } \\
(2008-2012)\end{array}$ & Total \\
\hline \multirow{2}{*}{ Gender } & Male & 38.5 & 41.3 & 40,4 \\
\hline & Female & 61.5 & 58.7 & 59,6 \\
\hline \multirow{3}{*}{ Age group } & $16-25$ & 14.8 & 47.8 & 37,3 \\
\hline & $26-45$ & 66.4 & 45.8 & 52,4 \\
\hline & $46+$ & 18.8 & 6.4 & 10,3 \\
\hline \multirow{2}{*}{ Marital status } & Married or in cohabitation & 54.7 & 53.1 & 53,6 \\
\hline & Single & 48.3 & 46.9 & 46,4 \\
\hline \multirow{2}{*}{ Family type } & Have children & 43.1 & 37.2 & 39,2 \\
\hline & Have no children & 56.7 & 62.8 & 60,8 \\
\hline \multirow{3}{*}{ Level of Education } & Primary & 10.0 & 17.6 & 15,2 \\
\hline & Secondary & 76.0 & 68.5 & 71,1 \\
\hline & Tertiary & 13.8 & 13.8 & 13,7 \\
\hline \multirow{6}{*}{$\begin{array}{l}\text { Current occupation in host } \\
\text { country }\end{array}$} & Low skilled & 23.0 & 36.8 & 32,4 \\
\hline & Skilled & 27.8 & 22.6 & 24,3 \\
\hline & Professionals & 24.2 & 13.9 & 17,2 \\
\hline & Students & 6.6 & 9.2 & 8,4 \\
\hline & Inactive & 12.2 & 13.7 & 13,5 \\
\hline & Unemployed & 5.7 & 3.6 & 4,2 \\
\hline \multirow{6}{*}{ Previous occupation in Latvia } & Low skilled & 20.0 & 15.8 & 17,1 \\
\hline & Skilled & 22.3 & 15.5 & 17,7 \\
\hline & Professionals & 26.6 & 26.3 & 26,4 \\
\hline & Students & 19.8 & 25.4 & 23,6 \\
\hline & Inactive & 4.8 & 5.8 & 5,5 \\
\hline & Unemployed & 6.5 & 11.4 & 9,8 \\
\hline \multirow{2}{*}{ Return intentions to Latvia } & Will return & 16.7 & 25.6 & 22,8 \\
\hline & Will not return & 83.3 & 74.4 & 77,2 \\
\hline \multirow{2}{*}{ Migration experience } & First time migration & 23,9 & 41,8 & 36,1 \\
\hline & Repeated migration & 76,1 & 58,2 & 63,9 \\
\hline \multirow{2}{*}{ Host country } & UK & 27,8 & 50,9 & 43,5 \\
\hline & Ireland & 44,4 & 14,5 & 24,1 \\
\hline
\end{tabular}




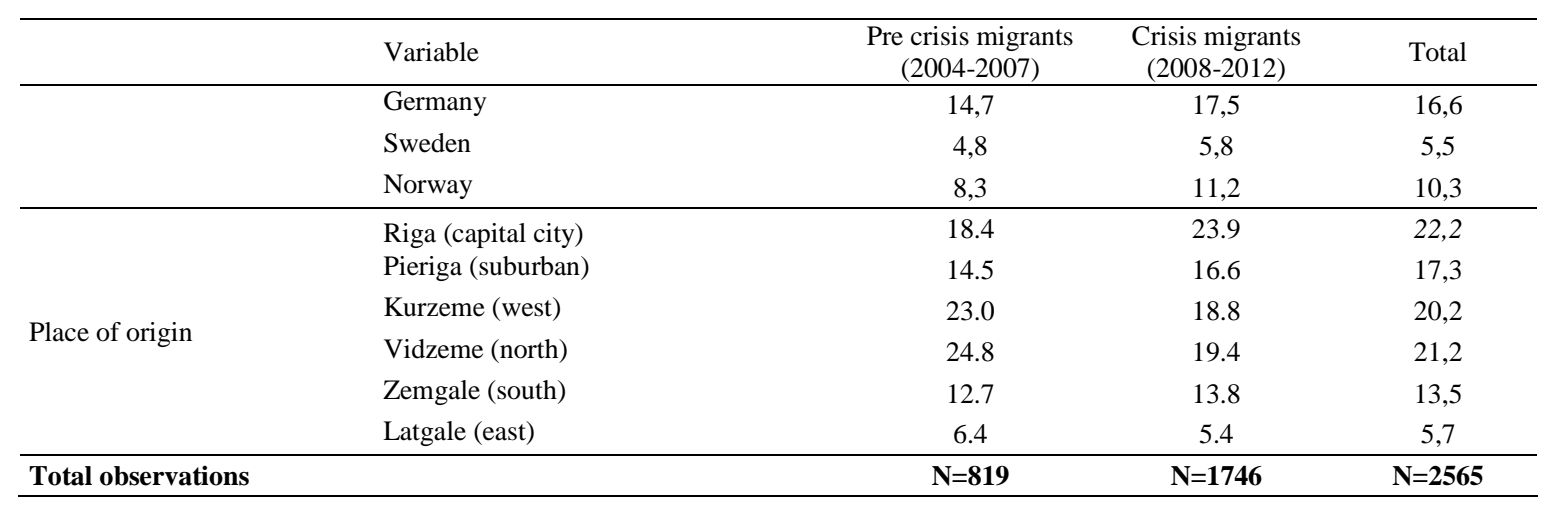

Table 2 highlights some consistency in the characteristics of migrants over the two periods, for example the sex and marital status balance remains relatively stable. Nonetheless, interpretation of these figures suggests that the recession has indeed significantly influenced the selectivity of migration from Latvia (Hazans, 2011). Recession migrants might thus be conceptualised as 'reluctant movers' relative to pre-crisis migrants, since their mobility can be attributed the emergence of powerful economic push factors. Unemployment prior to exit, migration for the first time, underemployment overseas and a desire to return infers that many recession migrants did not necessarily desire to migrate but instead were driven to seek employment opportunities overseas due to the onset of detrimental financial circumstances. This premise can be explored through an examination of the explanations offered by respondents for their mobility.

\section{Accession and Recession migrants: drivers of mobility}

Figure 1 below shows the motivations given by survey respondents for their moves from Latvia to other European countries. Whilst the categories below are rather broad, somewhat ambiguous and are by no means mutually exclusive, they do give an insight into the distinctive drivers of migration in the accession and recession contexts. Economic factors are a key motivator of mobility in general: employment opportunities elsewhere, economic uncertainty in Latvia and personal financial instability are key features of both phases of migration. From these figures both accession and recession migrants could mostly be categorised as labour migrants. However, recession migrants do appear to have been driven to migrate by economic factors to a greater extent than accession migrants. Reasons for the mobility of the latter group include adventure seeking and family factors to a greater extent than is evident amongst recession migrants. Likewise employment related factors and economic uncertainty in Latvia become much more prominent drivers of migration amongst 
recession migrants. Again these figures support the interpretation that the economic crisis has created new modes of mobility (Hazans, 2011); specifically 'reluctant' movers engaging in migration as a consequence of the emergence of powerful economic push factors in their home economy. It is worth cautioning at this stage that the categories used in the survey may have been interpreted differently by different types of migrants. For example quality of life considerations are known to be a relatively important factor in the mobility decisions of skilled crisis migrants (Triandafyllidou and Gropas (2014). As such 'uncertainty/missing perspectives' may actually relate to career progression or even lifestyle considerations as opposed to purely economic factors for this cohort. So whilst economic push factors account for much of the crisis migration wave, they do not fully explain it (note for example the diversity of 'previous occupation in Latvia' within the crisis cohort, Table 2).

Figure 1: Reasons given for migration

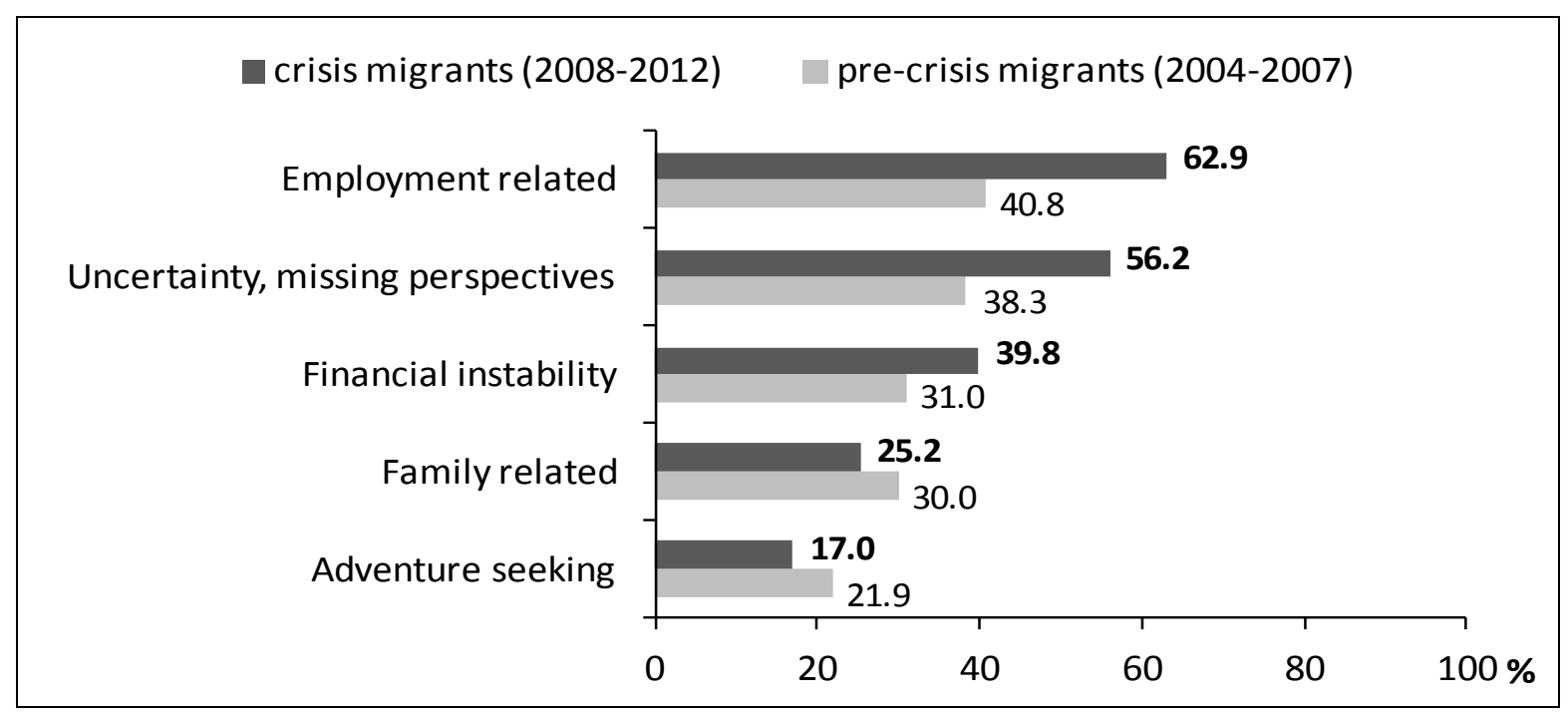

Note: respondents could choose up to three reasons in the survey

To test the supposition that the economic crisis has significantly altered the selectivity of recent migration trends, the survey data were subjected to a number of binary regression tests in order to examine the extent to which the characteristics of recession migrants were distinct from accession migrants. Model 1 (Table 3) tests the attributes that determine respondents' propensity to be an accession compared to recession migrant. Models 2 and 3 (Table 4) examine the extent of differential drivers and outcomes of mobility between the accession and recession periods. 
Table 3: Comparison of characteristics of accession (0) and recession (1) migrants, odds ratios

\begin{tabular}{lccc}
\hline Variable & \multicolumn{2}{c}{ Model 1} \\
\hline Gender (base: female) & B & Sig. \\
& Male & & \\
&, 183 &
\end{tabular}

Age group (ref.: 16-25)

$26-45$

$-2,199 * * *$

$46<$

$-3,109 * * *$

Marital status (ref.: married/in cohabitation) Single

Family status (base: have no children)

Have children

Level of Education (ref.: secondary)

Primary

$401 \quad * *$

Tertiary

$482 * * *$

Previous occupation in Latvia (ref.: low skilled)

Students

Inactive

$-, 359$

, 663

, $774 * * *$

Unemployed

, 275

skilled worke

Current occupation in host country (ref.: low skilled)

Students

$-, 662$

Inactive

,- 662
,- 223

Unemployed

skilled worker

$-, 800$

$-, 562$

Professionals

$-1,094$

Return intentions to Latvia (ref.: no)

Yes

Migration experience (ref.: first time)

Repeated

$-1,313 * * *$

Reason of emigration (ref.: other)

family related

employment related

financial instability (consumer credit, mortgage

payments

uncertainty, missing perspectives

adventure

$-, 304 * *$

Host country (ref.: Ireland)

UK

$2,054 \quad * * *$

Germany

1,965

Sweden

$1,837 * * *$

Norway

$2,133 \quad * * *$

Place of origin (ref.: Riga - capital city)

Pieriga (suburban)

$-, 027$

Kurzeme (west)

$-, 483 \quad * * *$

Vidzeme (north)

$-, 511$

Zemgale (south)

,269

Latgale (east)

$-, 709$

Constant $1,291 \quad * * *$

Level of significance: $* * * \mathrm{p}<0.01, * * \mathrm{p}<0.05, * \mathrm{p}<0.1$ 
The regression output displayed in Table 3 infers that the economic crisis has encouraged the mobility of both low skilled and highly skilled workers, with professionals and the unemployed showing greater propensities migrate in the recession than accession phase. Recessionary conditions in many host economies during the period 2008-2012, means that crisis migrants displayed increased likelihood of being in low skilled work whilst abroad than accession migrants. The fact that more recent migration was from Riga and was driven by financial instability and employment related reasons again suggests that economic push factors have become more prominent drivers of emigration from Latvia than was the case during the accession phase. Furthermore recession migrants were much more likely have been first time movers and displayed greater inclination towards return to Latvia.

In addition to identifying statistically meaningful differences between the accession and recession phases of recent Latvian emigration, binary regression techniques can also aid understanding of the factors that determine (a) labour driven as opposed to other drivers of migration from Latvia and (b) the likelihood of being in low skilled employment abroad after migration. These issues are of interest because they relate to the extent to which migration has been driven by economic factors and the labour markets outcomes of migrants once they elect to engage in international mobility. Such understandings can speak to debates about the labour market function of migrant labour, and how these dynamics interact with shifts in the business cycle (Fielding, 1997; Ahearne et al, 2009).

The factors that are associated with labour migration and engagement in low skilled work in destination states are displayed in Table 4. The category 'labour migrants' is derived from a distinct question in the survey which asked migrants to self-select a migratory group to which they felt they belonged. Alternative responses included: student migrant, family reasons and seeking an adventure overseas. Low skilled work is defined as being engaged in manual tasks whereas high skill work is categorised as managers, company owners and specialist skills workers. Many of the factors identified as being associated with labour migration relate to what might have been expected from the migration literature. Despite an increasing feminisation of migration, men tend to still dominate many labour driven flows, with women displaying a greater propensity to be categorised as family or student migrants (Schrover and Moloney, 2013). Similarly the findings that migrants with only primary levels of education are less likely to be labour migrants, ties in with the notion of human capital effects on the 
self-selectivity of migration (Chiswick, 2008). Finally disadvantageous personal financial circumstances appear to lead individuals towards becoming labour as opposed to other types of migrants, meeting historical assumptions that migration is primarily motivated by economic gain (Ravenstein, 1885).

Whilst the findings from model 2 in Table 4 confirm many widely held expectations about the nature of labour migration, the analysis of the factors that determine the likelihood of being in low skilled work in the destination country are perhaps more novel and interesting as they speak to continuing debates surrounding the function of migrant labour in relatively high wage economies, and the relationship between migrant labour and business cycles. The figures in model 3 contain a number of interesting findings in this respect. Firstly, female migrants were more likely to occupy low skilled jobs than male migrants, reflecting the relative labour market disadvantage of women in labour markets in general (Karamessini, 2013). In line with human capital models of migration, migrants holding a tertiary level education were less likely to find themselves in low skilled work abroad (Chiswick, 2008). Interestingly crisis migrants were more likely to be in low skilled work overseas than accession migrants. This could potentially be explained by a number of factors. Accession migrants will have spent longer in their host labour markets, thus increasingly their possibility of achieving more favourable labour market outcomes, as a consequence of improved language skills for example (Shields and Wheatley Price, 2001). Alternatively the emergence of severe economic push factors in Latvia may have meant that recession migrants were relatively accepting of undesirable pay and conditions abroad. This ties in with personal financial instability emerging as a significant determinant of subsequent employment in low skilled employment. Additionally poor labour market conditions in host labour markets may have restricted greater proportions of workers (migrant and non-migrant alike) to lower skilled employment opportunities. Migrants to the UK displayed a greater likelihood of being in low-skilled work, reflecting the relative prevalence of low paid employment and flexible labour market structures in that particular country (Migration Advisory Committee, 2014). Finally migrants from rural regions of Latvia were more likely to find themselves in low skill work abroad than those previously resident in Riga and its suburban hinterland. This could be a consequence of the residents of the capital city being seen as having high levels of human capital relative to countryside dwellers (Findlay et al, 2013). 
Table 4. Comparison of migrant groups: labour migrants (1) with others (0) (Model 2) and in low skilled occupations (1) with high skilled occupations aboard (0) (Model 3), odds ratios

\begin{tabular}{|c|c|c|c|c|}
\hline \multirow[t]{2}{*}{ Variable } & \multicolumn{2}{|c|}{$\begin{array}{c}\text { Model } 2 \\
\text { Self-defined } \\
\text { labour migrants } \\
\text { (1) }\end{array}$} & \multicolumn{2}{|c|}{$\begin{array}{c}\text { Model } 3 \\
\text { Migrants in low } \\
\text { skill work abroad } \\
\text { (1) }\end{array}$} \\
\hline & $\mathrm{B}$ & Sig. & $\mathrm{B}$ & Sig. \\
\hline Gender (base: female) & & & & \\
\hline Male & 1,795 & $* * *$ &,- 596 & $* * *$ \\
\hline $\begin{array}{l}\text { Age group }(\text { ref.: 16-25) } \\
26-45 \\
46+\end{array}$ & $\begin{array}{l}, 865 \\
, 984\end{array}$ & $\begin{array}{l}* * * \\
* * *\end{array}$ & $\begin{array}{l}-, 308 \\
-, 089\end{array}$ & $* *$ \\
\hline $\begin{array}{l}\text { Marital status (ref.: married, in cohabitation) } \\
\text { Single } \\
\text { Family status (base: have no children) }\end{array}$ & , 167 & & , 156 & \\
\hline Have children & ,695 & $* * *$ & ,064 & \\
\hline $\begin{array}{l}\text { Level of Education (ref.: secondary) } \\
\text { Primary } \\
\text { Tertiary }\end{array}$ & $\begin{array}{r}-, 525 \\
, 033\end{array}$ & $* * *$ & $\begin{array}{r}, 581 \\
-, 799\end{array}$ & $\begin{array}{l}* * * \\
* * *\end{array}$ \\
\hline $\begin{array}{l}\text { Return intentions to Latvia (ref.: no) } \\
\quad \text { Yes }\end{array}$ & ,263 & $*$ & ,237 & $* *$ \\
\hline $\begin{array}{l}\text { Period of emigration (ref.: pre-crisis, 2004-2007) } \\
\quad \text { crisis, 2008-2012 }\end{array}$ &,- 097 & & ,714 & $* * *$ \\
\hline $\begin{array}{l}\text { Migration experience (ref.: first time) } \\
\text { Repeated }\end{array}$ &, 171 & &,- 261 & $* *$ \\
\hline $\begin{array}{l}\text { Reason of emigration (ref.: other) } \\
\text { family related } \\
\text { employment related } \\
\text { financial instability (consumer credit, mortgage } \\
\text { payments) } \\
\text { uncertainty, missing perspectives } \\
\text { adventure }\end{array}$ & $\begin{array}{r}-, 538 \\
, 389 \\
, 434 \\
-, 165 \\
-, 068\end{array}$ & $\begin{array}{l}* * * \\
* * * \\
* * *\end{array}$ & $\begin{array}{l}, 048 \\
-, 015 \\
, 326 \\
-, 229 \\
-, 305\end{array}$ & $\begin{array}{l}* * \\
* *\end{array}$ \\
\hline $\begin{array}{l}\text { Host country (ref.: Ireland) } \\
\text { UK } \\
\text { Germany } \\
\text { Sweden } \\
\text { Norway }\end{array}$ & $\begin{array}{r}-, 012 \\
-, 382 \\
-, 529 \\
, 360\end{array}$ & $\begin{array}{l}* * \\
* *\end{array}$ & $\begin{array}{l}, 259 \\
-, 045 \\
-, 569 \\
-, 187\end{array}$ & $* *$ \\
\hline $\begin{array}{l}\text { Place of origin (ref.: Riga - capital city) } \\
\text { Pieriga (suburban) } \\
\text { Kurzeme (west) } \\
\text { Vidzeme (north) } \\
\text { Zemgale (south) } \\
\text { Latgale (east) } \\
\end{array}$ & $\begin{array}{l}-, 146 \\
, 393 \\
-, 109 \\
, 008\end{array}$ & $* *$ & $\begin{array}{l}-, 148 \\
, 360 \\
, 380 \\
, 286 \\
, 630 \\
\end{array}$ & $\begin{array}{l}* * \\
* * * \\
* \\
* *\end{array}$ \\
\hline Constant &,- 259 & $*$ &,- 665 & $* * *$ \\
\hline
\end{tabular}

Significance level: $* \mathrm{p}<0.10 * * \mathrm{p}<0.05 * * * \mathrm{p}<0.01$ 


\section{Discussion and conclusions}

This study sits within debates concerning the functions of migrant labour in relatively high wage economies and how these dynamics relate to shifts in the business cycle, as occurred in dramatic fashion with the onset of the Great Recession in 2008. There has been considerable interest in the migration literature and elsewhere in how immigrants fare in the labour markets of their host country. At a general level the existing body of evidence points towards migrants being disadvantaged in the labour market, both in terms of labour market participation levels and their distribution across the occupational hierarchy (Chiswick et al, 2008; McAllister, 1995). More recently these concerns have been given added urgency by the deep and ongoing economic turmoil which is affecting the economies of many migrant labour sending and receiving countries (Orrenius and Zavodny, 2010; Green and Winters; 2010). Whilst some existing research has explored the impact of the recession on the economic wellbeing of migrants, less attention has been paid to how the selectivity of migration from lower to higher wage regions have been affected by the unprecedented economic turmoil of the Great Recession. This analysis has thus sought to shed light on a potentially novel aspect of contemporary European migration, the crisis migrant.

Conceptually the analysis is underpinned by longstanding assumptions that international migration is chiefly, although not exclusively, driven by economic factors (Ravenstein, 1885). Migration is a self-selecting process, with relatively able individuals displaying a greater propensity to become migrants (Chiswick, 2008). However migration does not exist independently of wider political and economic structures, and it was for this reason that Latvia was selected as an empirical lens through which the relationship between migration and the business cycle could be explored. Recent migration from Latvia can be categorised into three very distinct phases, each with different potential patterns and processes of mobility. Firstly the removal of legislative barriers to mobility in 2004 led to migration towards higher wage labour markets, particularly the UK and Ireland (accession migrants). Secondly, buoyant labour market conditions before the advent to the Great Recession was associated with lower emigration rates and some return migration. Finally the economic turmoil created by the Great Recession has produced significant flows of migrants from Latvia (crisis migrants). These trends are in some ways distinct from the recent migration experiences of the A8 states. The Latvian economy performed relatively strongly following 
the accession, but was severely affected by the Great Recession. As a consequence, emigration rates were relatively low in the accession period but comparatively high in the recession phase relative to many other East-Central European states. A chief objective of this research has been to examine how the changing political and economic context against which recent migration has occurred has produced quantitatively and qualitatively different types of mobility.

The findings from this investigation confirm that labour market considerations have consistently been the main driver of recent emigration from Latvia. Both accession (emigrated 2004-2007) and recession (emigrated 2008-2012) migrants were chiefly motivated by economic drivers (Figure 1). However economic push factors have become more important determinants of migration as the Latvian economy has suffered as a consequence of the Great Recession. The higher incidence of unemployment prior to exit, unemployed and professional movers, initial migration moves, underemployment overseas and a stated desire to return indicates that recession migrants can be classed as 'reluctant movers'. Whilst the motivation categories used in this investigation were somewhat ambiguous, and continuity and internal diversity existed between and within the accession and crisis migrant groups, analytically, the economic crisis can be thought of as creating new modes of intra-EU mobility, that of reluctant movers engaging in migration as a consequence of the emergence of severe economic push factors in their home country. These recession migrants are relatively prone to being in low-skilled work once they do engage in international mobility and are susceptible to underemployment. These findings relate to wider debates about the function of migrant labour in relatively high wage economies, and how their labour market prospects are affected by shifts in the business cycle, as typified by the Great Recession (Findlay et al, 2010; Fix et al, 2009).

To conclude, this analysis has contributed to an emerging body of literature in migration studies which focuses on the extent to which the unprecedented economic turmoil of the Great Recession has impacted on the selectivity of migration systems within the context of the free movement of labour within Europe. The mobility of so-called crisis migrants is an important research agenda since these movements may represent novel developments in terms of recent 
intra-EU mobility; that of reluctant movers compelled into becoming international migrants due to the emergence of severe economic push factors in their home countries. The assertion that economic push factors are conductive to emigration from East-Central European or indeed other comparatively low-wage countries is not a novel one. Likewise not all crisis migration has been driven by purely economic factors. However the distinctive contribution of this analytical perspective is that it has examined the shifting selectivity of international migration against the backdrop of (a) significant spatial disparities in earning potential, (b) the abrupt removal legislative barriers of mobility and (c) dramatic shifts in the business cycle. As such the questions raised in this investigation have relevance far beyond the confines of Latvia. Potentially fruitful avenues of future research in this respect could explore the longer term mobility patterns of these reluctant movers, and their policy implications in both sending and destination countries. Eastern and Southern European countries have lost large numbers of talented individuals through migration as a consequence of the Great Recession, will these reluctant migrants be able to return, and if not then what will be the demographic and economic ramifications of the current phase of crisis migration? Migration scholars have an obligation, and are well placed, to engage with these pressing questions.

\section{Acknowledgement}

The work was funded by the National Research Programme [grant number 5.2.4] and the Latvian Council of Sciences [grant number 514/2012].

\section{References}

- Ahearne, A. Brucker, H. Darvas, Z. and Van Weizsacker, J. (2009). Cyclical Dimensions of Labour Mobility after EU Enlargement. Bruegel Working Paper 2009/03. Available at: http://www.kti-ie.hu/file/download/mtdp/MTDP0910.pdf.

- Bakewell, O. de Haas, H. and Kubal, A. (2011). 'Migration systems, pioneers and the role of agency'. International Migration Institute Working Papers Series. University of Oxford. Oxford.

- Bakewell, O. A, Kubal. and S, Pereira. (2016). 'Introduction: Feedback in Migration Processes'. In O, Bakewell. G, Engbersen. M.L. Fonseca and C, Horst (eds) Beyond Networks Feedback in International Migration. Palgrave Macmillan. London. pp 117.

- Blanchard J.O., Griffiths, M. and Gruss, B. (2013). Boom, Bust, Recovery: Forensics of the Latvia Crisis. Brooking Papers on Economic Activity, Fall 2013. 325 - 388.

- Blanchflower, D. Saleheen, J. and Shadforth, C. (2007). 'The Impact of the Recent Migration from Eastern Europe on the UK Economy'. Institute for the Study of Labour, Discussion Paper Number 2615. Available at: ftp://ftp.iza.org/dps/dp2615.pdf 
- Bleiere, D., Butulis, A., Feldmanis, I., Stranga, A. and Zunda, A. (2005). History of Latvia, 20th Century, Jumava, Riga (rev. ed.).

- Boyd, D, Ellison, N. B. (2007). Social network sites: Definition, history, and scholarship. Journal of Computer of. Mediated Communication, 13(1), 210-230.

- Burrell, K. (2009). Introduction. In: Burrell K (ed.) Polish Migration to the UK in the 'New' European Union. Farnham Ashgate, 1-22.

- Bygnes, S (2015). 'Are they leaving because of the crisis?' Sociology. Online early view.

- Castles, S., Miller, M.J. (2009). The Age ofMigration: International Population Movements in the Modern World (4th edition). Basingstoke: Palgrave MacMillan

- Chiswick, B. (2008). 'Are Immigrants Favourably Self-Selected?' In: C. Brettel and J. Hollifield (eds) Migration Theory, pp. 63-82 (London: Routledge).

- Chiswick, B. Anh, L. and Miller, P. (2008). How Immigrants Fare across the Earnings Distribution in Australia and the United States. Industrial and Labor Relations Review 61(3): 353-373.

- de Haas, H. (2010). 'The Internal Dynamics of Migration Processes: A Theoretical Inquiry'. Journal of Ethnic and Migration Studies 36. pp 1587-1617.

- Dekker, R., Engbersen, G., and Faber, M. (2015), The Use of Online Media in Migration Networks.Popul. Space Place, doi: 10.1002/psp.1938

- Dekker, R. Engbersen, G. and Faber, M. (2016). 'Online Feedback in Migration Networks'. In O, Bakewell. G, Engbersen. M.L. Fonseca and C, Horst (eds) Beyond Networks Feedback in International Migration. Palgrave Macmillan. London. pp 6989.

- Dustmann, C. and Weiss, Y. (2007). Return Migration: Theory and Empirical Evidence from the UK. British Journal of Industrial Relations. Vol 42 no 2. 236-56

- Dustmann, C. Frattini, T. and Halls, C. (2010). 'Assessing the fiscal costs and benefits of A8 migration to the UK'. Fiscal Studies 31 (1). pp 1-41.

- Eglīte, P. (2009). A Brief Overview of 20th Century Latvian Migration Studies. Folia Geographica, 14. 81-87.

- Eurostat (2010) Europe in Figures, Eurostat Yearbook 2010. Luxembourg: Eurostat Statistical Books.

- Eurostat (2014) Statistics Explained, Internet use and frequency of use, 2014. Available at: $\quad$ http://ec.europa.eu/eurostat/statisticsexplained/index.php/File:Internet_use_and_frequency_of_use,_2014_\%28\%25_of_in dividuals\%29.png

- Fielding, A. J. (2007). The effects of economic restructuring on the population distribution of Western Europe's cities and regions. In: H. Blotevogel and A. J. Fielding (eds) People, Jobs and Mobility in the New Europe, pp. 297-304 (Chichester: Wiley).

- Findlay, A. Geddes, A. \& McCollum, D. (2010). International Migration and Recession. Scottish Geographical Journal, Vol 126 (4), 299-320. 
- Findlay, A. McCollum, D. Shubin, S. Apsite, E. and Krisjane, Z. (2013). 'The role of recruitment agencies in imagining and producing the 'good' migrant'. Social and Cultural Geography. 14(3). pp 145-163.

- Fix, M. Papademetriou, D. Batalova, J. Terrajas, A. Yi-Ying Lin, S. and Mittelstadt, M. (2009). Migration and the Global Recession. Migration Policy Institute. Available at: http://www.migrationpolicy.org/pubs/MPI-BBCreport-Sept09.pdf

- Galea, S., Tracy, M. (2007). Participation rates in epidemiologic studies. Annals of epidemiology, 17(9), 643-653.

- Gillingham, E. (2010). Understanding A8 migration to the UK since accession. Office for National Statistics.

- Green, T. and Winters, L. (2010). Economic Crises and Migration: Learning from the Past and the Present. The World Economy 33(9): 1053-1072.

- Hamel, J.-Y. (2009). Information and communication technologies and migration. Geneva: United Nations Development Programme

- Hansen, K.M. and Pedersen, R.T. (2012). Efficiency of different recruitment strategies for web panels. International Journal of Public Opinion Research 24(2): 238-249.

- Hargittai, E. (2008). How Wide a Web? Inequalities in Accessing Information Online. Sociology Department, Princeton University

- Hazans, M. (2011). Latvijas emigrācijas main̄̄gā seja: 2000-2010. “Latvija. Pārskats par tautas attīstību 2010./2011. Nacionālā identitāte, mobilitāte un rīcībspēja" (red. Brigita Zepa un Evija Kḷave). Rīga: LU Akadēmiskais apgāds: 70-91. ISBN 9789984-45-414-6.

- Hazans, M. 2011. "The Changing Face of Latvian Emigration, 2000-2010.” In Latvia Human Development Report 2010/2011: National Identity, Mobility and Capability, ed. by Brigita Zepa and Evija Klave. Riga: Advanced Social and Political Research Institute of the University of Latvia.

- Hazans, M. (2012). 'Selectivity of migrants from Baltic countries before and after enlargement and response to the crisis'. In B. Galgczi, J. Leschke and A. Watt (eds) EU labour migration in troubled times. Routledge. London. pp 169-208.

- Internet Association of Latvia (2015). Available at: http://www.lia.lv/interneta_lietotaji/.

- Kaczmarczyk, P. and Okólski, M. (2008). Demographic and labour market impacts of migration on Poland. Oxford Review of Economic Policy, Volume 24, Number 3, 2008, pp.599-624

- Kahanec, M., Zaiceva, A., Zimmermann, K., F. (2009). Lesson for Migration after EU enlargement. IZA Discussion Paper No. 4230.

- Kancs, d'A. (2010). The economic geography of labour migration: competition, competitiveness and development, Applied Geography 31(1): 191-200.

- Karamessini, M. (2013). 'Introduction - women's vulnerability to recession and austerity'. In M. Karamessini and J. Rubery (eds) Women and Austerity. Routledge. London. pp 3-16. 
- Kellerman, A. (2010). Mobile broadband services and the availability of instant access to cyberspace. Environment and Planning A 42(12) 2990 - 3005

- King. R., Lulle, A. Conti, F. Mueller, D. and Scotto, G. (2014). The lure of London: A comparative study of recent graduate migration from Germany, Italy and Latvia. Sussex Centre for Migration Research, Working Paper No. 75 07/2014

- Koyama, Y. (2010). Economic crisis in new EU Member States in Central and Eastern Europe, Romanian Economic and Business Review 5(3): 31-55.

- Lindstrom D.P. and Ramirez, A.L. (2010). Pioneers and Followers: Migrant Selectivity and the Development of U.S. Migration Streams in Latin America. Ann Am Acad Pol Soc Sci. 2010 July; 630(1): 53-77. doi: 10.1177/0002716210368103

- McAllister, I. (1995). Occupational Mobility among Immigrants: The Impact of Migration on Economic Success in Australia. International Migration Review 29(2): 441-468.

- McCollum, D. and Findlay, A. (2015). 'Flexible' workers for 'flexible' jobs? The labour market function of A8 migrant labour in the UK. Work, Employment \& Society; vol. 29, 3: pp. 427-443.

- McCollum, D. (2013). 'Investigating A8 migration using data from the Worker Registration Scheme: temporal, spatial and sectoral trends'. Local Economy Vol. 28 No 1. pp 35-50.

- McCollum, D. Shubin, S. Apsite, E. and Krisjane, Z. (2013). 'Rethinking Labour Migration Channels: the Experience of Latvia from EU Accession to Economic Recession'. Population, Space and Place Volume 19. Issue 6. pp 688-702.

- McCollum, D., Apsite-Berina, E. (2015). Recruitment through migrant social networks from Latvia to the United Kingdom: Motivation, Processes and Development. Forthcoming at Migration Letters, Volume 12, No:1.

- Migration Advisory Committee (2014) Migrants in low-skilled work. London: MA

- Oiarzabal, P. (2012). Diaspora Basques and online social networks: an analysis of users of Basque institutional diaspora groups on Facebook. Journal of Ethnic and Migration Studies 38 (9) 1469-1485

- Okólski, M. and Salt, J. (2014). Polish emigration to the UK after 2014: Why did so many come? Central and Eastern European Migration Review 3(2): 11-37.

- Orrenius, P. and Zavodny, M. (2010). Mexican Immigrant Employment Outcomes over the Business Cycle. American Economic Review: Papers \& Proceedings 100: 316-320.

- Portes, A. and Sensenbrenner, J. (1993). Embeddedness and immigration: Notes on the social determinants of economic action. American Journal of Sociology 98(6): 1320-1350.

- Ravenstein, E. C. (1885). 'The laws of migration'. Journal of the Royal Statistical Society 48(2). pp 167-245.

- Reips, U. and Buffardi E.L. (2012). Studying Migrants with the Help of the Internet: Methods from Psychology, Journal of Ethnic and Migration Studies, 38:9, 1405-1424 
- Salt, J. (2008). International Migration and The United Kingdom. Report of the United Kingdom Sopemi correspondent to the OECD

- Schrover, M. and Moloney, D. (2013). 'Gender, Migration and Categorisation'. Amsterdam University Press. Amsterdam.

- Shields, M. A. and Wheatley Price, S. (2001). Language fluency and immigrant employment prospects: evidence from Britain's ethnic minorities Applied Economics Letters 8: 741-745.

- Somerville, W. and Sumption, M. (2009). 'Immigration in the United Kingdom: The recession and beyond'. Migration Policy Institute. Available at: http://www.migrationpolicy.org/pubs/Immigrationin-the-UK-The-Recession-and-Beyond.pdf.

- Stenning, A. and Dawley, S. (2009). 'Poles to Newcastle: Grounding new migrant flows in peripheral regions'. European Urban and Regional Studies, 16(3). pp 273294.

- Tammaru, T., Kumer-Haukanõmm, K., Anniste, K. (2010). The formation and development of the Estonian diaspora. Journal of Ethnic and Migration Studies, 36(7), 1157 - 1174.

- Triandafyllidou, A. and Gropas, R. (2014). 'Voting with their feet'. American Behavioural Scientist 58(12). pp 1614-1633.

- Waldinger, R. and Lichter, M. (2003). How the other half works: immigration and the social organisation of labour. Berkley: University of California Press.

- Weisbrot, M. and Ray, R. (2010). Latvia's Recession. Washington DC: Centre for Economic and Policy Research, http://www.cepr.net/documents/publications/latviarecession-2010-02.pdf

- Woolfson, C. (2009). Labour migration, neoliberalism and ethno-politics in the New Europe: the Latvian case, Antipode 41(5): 952-982.

- Zaicev, A. and Zimmerman, K. (2012). Returning Home at Times of Trouble? Return Migration of EU Enlargement Migrants during the Crisis. IZA Discussion Paper 7111. 